\title{
Cone Beam Computed Tomographic Characterization of Short Root Anomaly in Chloroquine-Induced Stevens-Johnson Syndrome - a Case Report
}

\author{
Vijay Yadav, Sidhartha Sharma, Vijay Kumar, Amrita Chawla, Ajay Logani \\ Conservative Dentistry and Endodontics, Centre for Dental Education and Research, All India Institute of Medical Sciences, New Delhi, India
}

Corresponding author: Vijay Yadav, Conservative Dentistry and Endodontics, Centre for Dental Education and Research, All India Institute of Medical Sciences, 110029 New Delhi, India; E-mail: Id-dr.vjyadav@gmail.com

Received: 31 Aug 2020 Accepted: 11 Mar 2021 Published: 28 Feb 2022

Citation: Yadav V, Sharma S, Kumar V, Chawla A, Logani A. Cone beam computed tomographic characterization of short root anomaly in chloroquine-induced Stevens-Johnson Syndrome - a case report. Folia Med (Plovdiv) 2022;64(1):169-75. doi: 10.3897/folmed.64. e58178.

\begin{abstract}
Stevens-Johnson syndrome (SJS) is a rare medical condition with severe mucocutaneous reaction due to infection or adverse drug reaction. The present case reports the impact of chloroquine-induced SJS on the tooth root development. A 20-year-old Indian male reported to conservative dentistry and endodontics speciality clinic with the chief complaint of food lodgement and sensitivity in maxillary and mandibular posterior teeth. He had a past medical history of severe cutaneous reaction after taking Tab. Lariago (chloroquine) for treatment of malarial fever at the age of 8 years. The acute inflammatory immune response was managed by hospitalization and administration of steroids and anti-inflammatory drugs. Clinical examination revealed dry mucosa, carious teeth with adequate oral hygiene. Panoramic X-ray showed multiple teeth with short roots. A detailed cone beam computed tomographic scan (CBCT) demonstrated a healthy bone trabecular pattern with the absence of any periapical radiolucency. Short, blunt roots with immature apex were seen in many teeth. Based upon the measurement of root to the crown ratio on the CBCT scan and correlating the development status of teeth with the medical history, a diagnosis of short root anomaly (SRA) after chloroquine-induced SJS was made. This is the first report to describe the three-dimensional features of teeth with SRA in a patient with SJS. Diagnostic, restorative, and endodontic implications of SJS are highlighted.
\end{abstract}

\section{Keywords}

rhizomicry, short root anomaly, Stevens-Johnson syndrome

\section{INTRODUCTION}

Stevens-Johnson syndrome (SJS) is a rare medical condition with a prevalence of 7.1 per million people. ${ }^{1}$ It is characterized by exudative multiform erythema, stomatitis, conjunctivitis (sometimes leading to keratitis and panophthalmitis), and severe constitutional symptoms. ${ }^{2} \mathrm{Al}-$ though the aetiology includes infections like mycoplasma pneumonia, vaccine, graft vs. host reaction, and idiopathic disease, it is most commonly associated with an adverse reaction to certain drugs. ${ }^{3}$ SJS is classified into three types: erythema multiform (smooth form), SJS (main form), and toxic epidermal necrolysis (TEN) (severe form), depending on the total body surface area affected by an adverse drug reaction. ${ }^{4}$ Pathogenesis and clinical presentation are similar for SJS and TEN, differing only on their extent of skin detachment following severe epidermolysis. ${ }^{5}$

Cutaneous sequelae are the most common long-term 
complications of SJS, including post-inflammatory dyspigmentation, abnormal scarring, eruptive naevi, and nail changes. ${ }^{6}$ The risk of nail involvement (onychoma, dystrophy, anonychia, pterygium, ridging, streaky pigmentation, and longitudinal nail ridges) is related to the severity of the disease. $^{7}$ Chronic ocular sequelae are the most disabling complication seen in all three forms of SJS, which can lead to partial or absolute loss of vision. Oral complication primarily includes xerostomia and difficulty in mastication or deglutination. ${ }^{6}$ Dental growth abnormalities due to SJS range from dental agenesis, root dysmorphia, short root, microdontia, and incomplete root apex closure, depending upon its time of onset, i.e., during primary or mixed dentition. ${ }^{8-10}$ The short root anomaly (SRA) with immature apex can present as a diagnostic dilemma and treatment challenge for endodontists. This paper aims to report 3D conebeam computed tomographic (CBCT) features of SRA in the case of SJS and to discuss their diagnostic, restorative, and endodontic implications.

\section{CASE REPORT}

A 20-year-old Indian male was referred to the Conservative Dentistry and Endodontics specialty clinic with a chief complaint of sensitivity and food lodgement in maxillary and mandibular posterior teeth on both sides. His past medical history was remarkable for severe illness at the age of 7 years. Medical records indicated that the patient had an acute episode of erythema and skin desquamation all over the body along with conjunctivitis and oral ulceration one day after taking chloroquine tablet (Tab. Lariago ${ }^{\mathrm{TM}}$, Ipca Laboratories Pvt. Ltd., India) for the treatment of malaria. A diagnosis of
SJS due to the adverse reaction of chloroquine was made at that time. He was hospitalized for a month and prescribed topical steroids and analgesics to treat the disease condition. Although the skin lesions healed at the time of discharge, there was persistent irritation and dryness of eyes. This condition gradually progressed into partial loss of vision at the age of 12 years for which he underwent corneal transplant surgery. He had a dental history of extraction of tooth \#47 due to increased mobility 18 months ago. There was no previous history of dental trauma or orthodontic treatment.

The patient's height (164 cm), weight (54 kg), BMI (20.6), and intelligent quotient were within the normal range. Clinical examination revealed mottled pigmentation on the face and bilateral blepharitis (Fig. 1A). Malformed nails with pterygium and longitudinal ridge formation were also noticed in upper and lower limbs (Figs 1B, 1C). On intraoral examination, dryness of oral mucosa was observed. Oral hygiene was satisfactory, with no signs of gingival inflammation. Hypoplastic enamel was present on the buccal surfaces of both maxillary and mandibular second premolars on the left side. Deep dentinal carious lesions were present in teeth (\#17, 26, 27, 37, 36, and 46). Bilateral maxillary lateral incisors (\#12 \& 22) and right mandibular first premolar (\#44) were congenitally missing (Figs 1D, 1F).

Orthopantomogram (OPG) (Villa system medical) revealed multiple teeth in maxillary and mandibular jaw with abnormal short roots with blunting at root apex and an impacted tooth in mandibular jaw. There was no radiographic evidence of periapical pathology, and the trabecular bone pattern was normal (Fig. 2). All teeth responded positively to cold and electric pulp sensibility tests. The periodontal probing depth and tooth mobility were within physiologic limits for all the teeth. The patient was asked to chew on paraffin
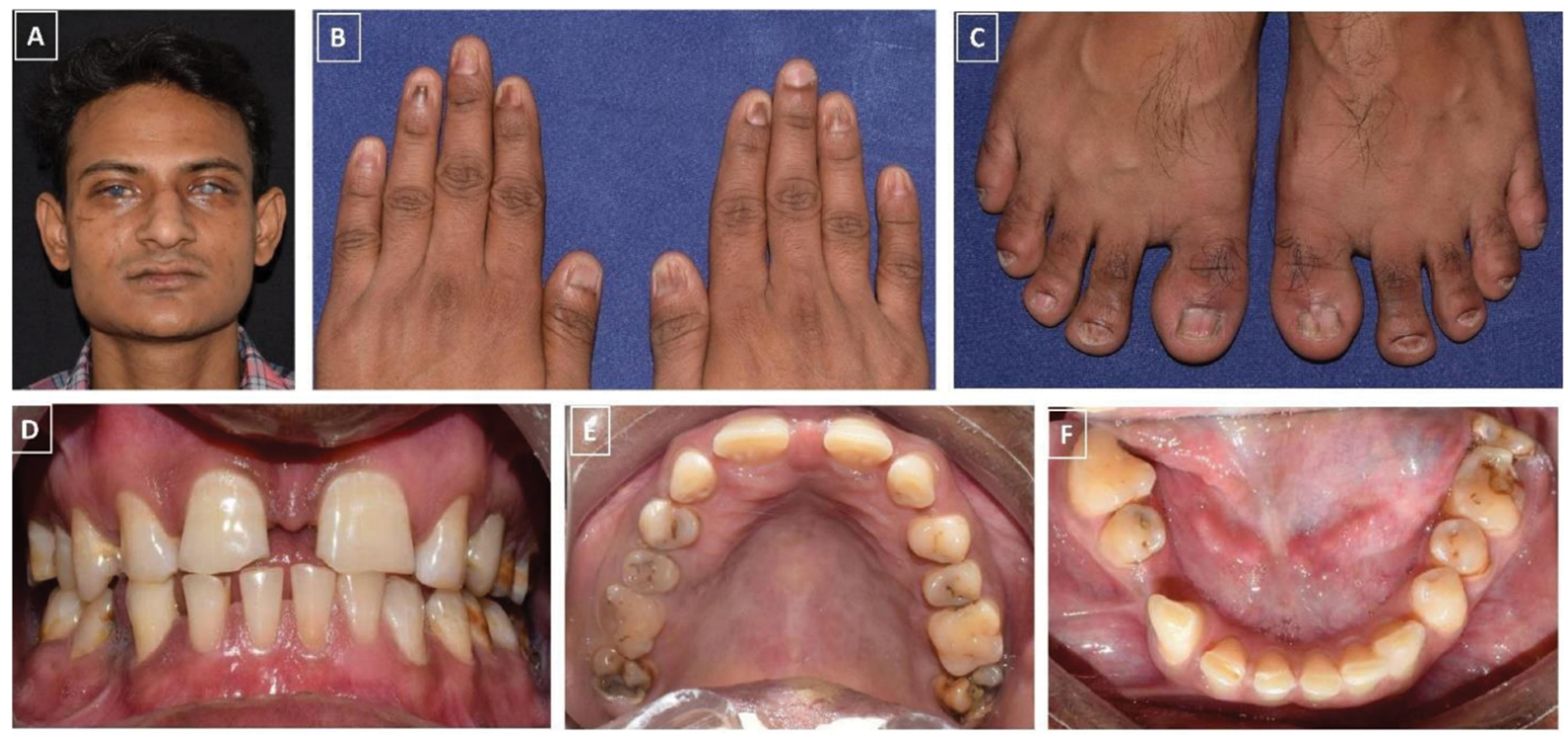

Figure 1. A. Mottled pigmentation on the face and bilateral blepharitis; B. Malformed nails with pterygium and longitudinal ridge formation in upper limbs; C. Malformed nails with pterygium and longitudinal ridge formation in lower limbs; D. Intraoral labial view; E. Maxillary occlusal view; F. Mandibular occlusal view. 


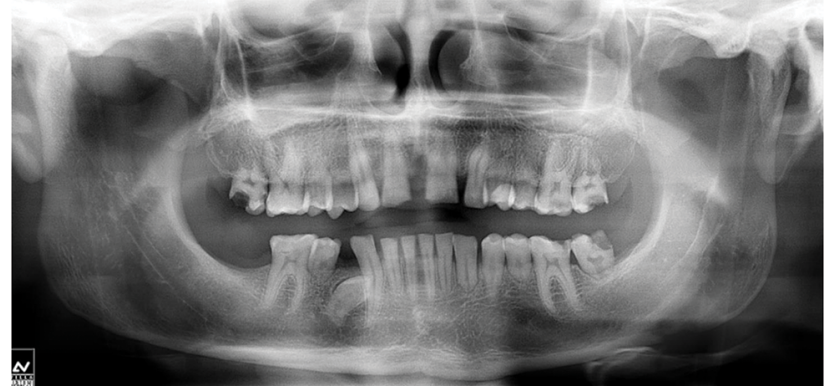

Figure 2. Orthopantomogram showing short root in teeth \# 17, $15,14,24,25,27,37,35,33$, and 45 . Impacted tooth \#44 is also seen.

wax, and the saliva sample was collected in a measuring container for 5 minutes. The stimulated saliva flow rate of $0.5 \mathrm{ml} / \mathrm{min}$ indicated towards decreased salivation. Haematological parameters (urea, creatinine, alkaline phosphatase, SGPT, SGOT, calcium, uric acid, phosphate, total cholesterol) were within the normal range. The family history was non-contributory.

To further investigate the atypical finding of short roots in multiple teeth, a CBCT scan $(16 \times 8 \mathrm{FOV}, 0.2 \mathrm{~mm}$ voxel size) was advised. The CBCT images were stored in DICOM format and viewed using Carestream 3D software (Carestream Health Inc.) on an HP 21-inch LED monitor with a resolution of $1280 \times 1024$ under ambient light conditions. The scan was evaluated in coronal, sagittal, and transverse planes using oblique slicing mode by a single operator (VY). Abnormal incompletely formed root with funnel-shaped apical root canal opening was seen with relation to teeth \#17,27, and 37. Root with blunt apices and onion-like appearance was noticed in teeth \#15,14,24, 25, 35, 33, 42, and 45, including the impacted tooth \#44 (Fig. 3). Apical foramen of diameter $>1 \mathrm{~mm}$ was noticed with relation to teeth \#17, 15, 14, 24, 25,27 , and 37. Rest all teeth had complete root formation with closed apex. The root/crown $(R / C)$ ratio for the teeth was measured on the CBCT scan using methods given by Choi et al. (Fig. 4). ${ }^{11}$ A reference line was drawn by joining highest point on labial and palatal CEJ in the sagittal section.

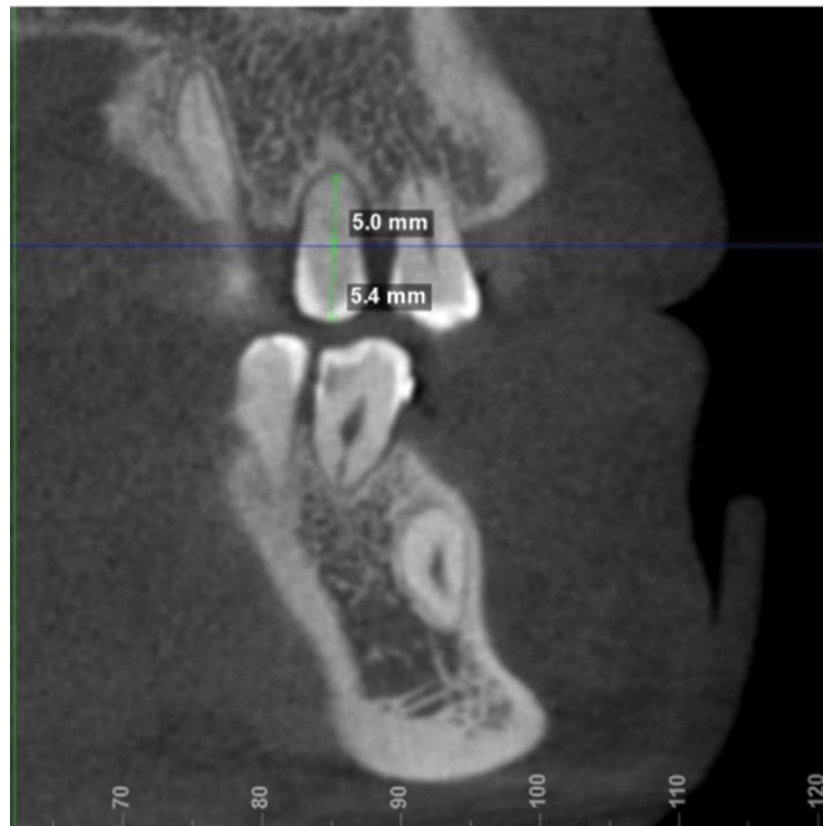

Figure 4. Measurement of root and crown length, line joining cementoenamel junction is taken a reference line. Distance from cusp tip and root apex to the reference line is considered as crown and root length, respectively.

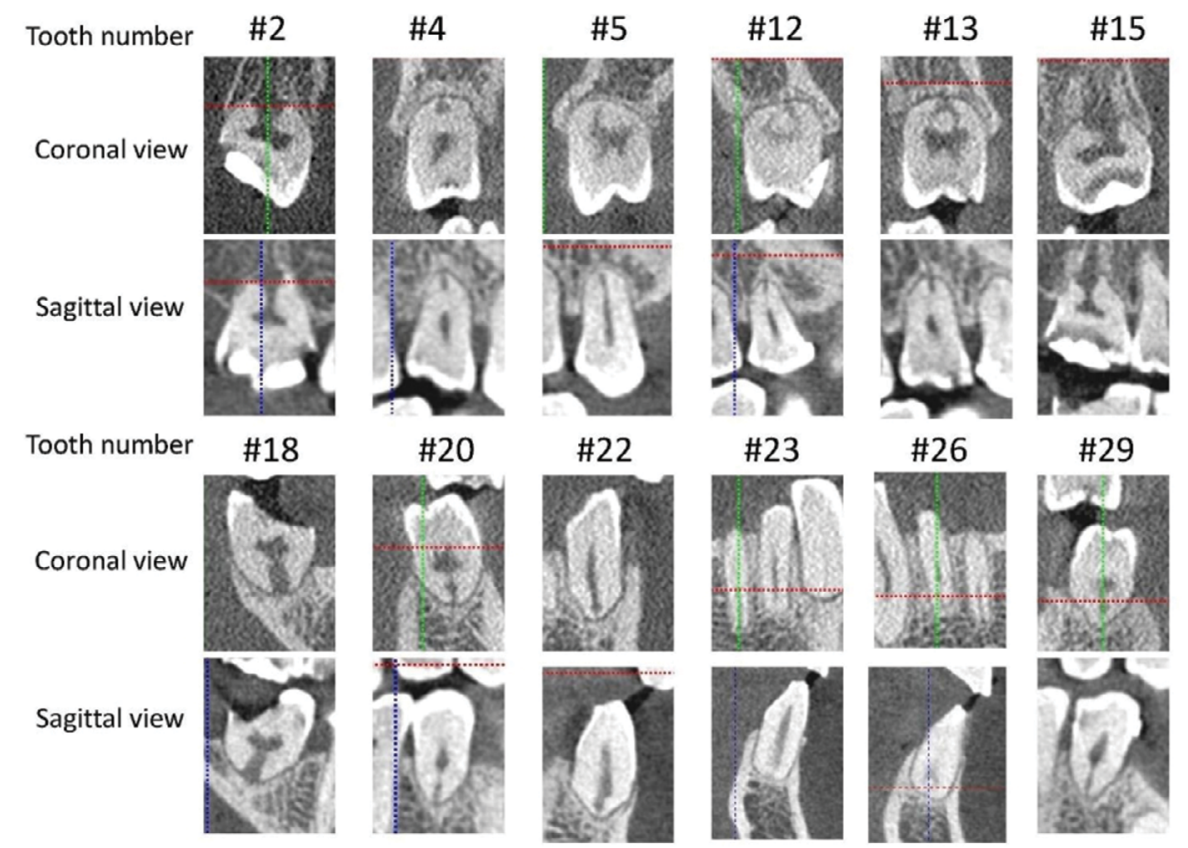

Figure 3. $\mathrm{CBCT}$ images of teeth with malformed root in coronal and sagittal cross section. The apical features are explained in Table $\mathbf{1 .}$ 
A distance on perpendicular drawn from the reference line to the incisal tip and root apex was used to measure crown and root length respectively. Teeth \#17, 14, 24, 25, 27, 37, 35, 33, $32,26,42$, and 45 were categorized as $S R A$ according to $R / C$ ratio $<1.1$ (Table 1).

Based on medical history, clinical, and radiographic examination, the diagnosis of SRA in multiple teeth due to SJS syndrome was established. The conservative treatment plan was made, and all the carious lesions were restored with resin composite material (Tetric-E-Ceram Bulk Fill; Ivoclar-Vivadent, Schaan, Liechtenstein). Thereafter, a regular follow-up was planned. Informed consent was taken from the patient regarding the publication of the case records.

\section{DISCUSSION}

SRA is a disorder of tooth root development resulting in abnormal root morphology characterized by short and blunt roots. ${ }^{12}$ The prevalence of SRA ranges from $0.6 \%$ to
$10 \%$ with female predilection. ${ }^{13,14}$ The genetic factors (dentin dysplasia, dentinogenesis imperfecta), systemic diseases (hypoparathyroidism, hypocalcemia, thalassemia), environmental insult (trauma, chemotherapy, radiotherapy, orthodontic forces) and syndromic disorders (scleroderma, Down syndrome, and Laurence-Moon-Bardet-Biedl syndrome) can be attributed to the development of SRA. ${ }^{13-15}$ The differential diagnosis includes conditions in which the generalized root development cessation is often seen. In the absence of any other plausible explanation, SRA, in this case, could be attributed as a consequence of a fulminant attack of SJS after adverse drug reaction. This is in concurrence with literature where SRA is reported secondary to SJS. ${ }^{8}$ Antibacterial sulphonamides, anticonvulsants, and NSAIDs have been reported as the most common causative drug for SJS. ${ }^{16}$ In the present case, the intake of chloroquine was exclusively responsible for the attack of SJS. The most critical strategy for the management of SJS is the prevention of early disease progression. However, the disease has various long-term sequelae. The clinical findings of cuta-

Table 1. Linear measurements of root length, crown length, tooth length, root to crown ratio and apical root morphology of teeth seen on CBCT scan

\begin{tabular}{|c|c|c|c|c|c|}
\hline \multirow[b]{2}{*}{ Tooth no. } & \multicolumn{4}{|c|}{ Tooth dimensions } & \multirow[b]{2}{*}{ Apical root end features } \\
\hline & $\begin{array}{l}\text { Root length } \\
(\mathrm{mm})\end{array}$ & $\begin{array}{l}\text { Crown length } \\
(\mathrm{mm})\end{array}$ & $\begin{array}{l}\text { Tooth length } \\
(\mathrm{mm})\end{array}$ & $\begin{array}{l}\text { Root/ crown } \\
(\mathrm{R} / \mathrm{C}) \\
\text { ratio }\end{array}$ & \\
\hline $17^{\star}$ & 4.7 & 6.3 & 11.0 & 0.74 & Funnel shaped immature apex \\
\hline 16 & 12.4 & 5.4 & 17.8 & 2.30 & Mature tapering apex \\
\hline 15 & 6.5 & 5.6 & 12.1 & 1.16 & Immature apex with root end blunting \\
\hline $14^{*}$ & 6.3 & 5.8 & 12.1 & 1.08 & Immature apex with root end blunting \\
\hline 13 & 16.9 & 8.0 & 24.1 & 2.10 & Mature and tapering apex \\
\hline 11 & 11.4 & 8.9 & 20.3 & 1.28 & Mature apex with slight blunting seen \\
\hline 21 & 11.3 & 8.8 & 20.1 & 1.28 & Mature apex with slight blunting seen \\
\hline 23 & 14.6 & 7.0 & 21.6 & 2.08 & Mature with tapering apex \\
\hline $24^{*}$ & 6.0 & 5.9 & 11.9 & 1.01 & Immature apex with root end blunting \\
\hline $25^{\star}$ & 5.5 & 5.7 & 11.2 & 0.96 & Immature apex with root end blunting \\
\hline 26 & 12.3 & 5.3 & 17.6 & 2.3 & Mature tapering apex \\
\hline $27^{\star}$ & 5.4 & 5.9 & 11.3 & 0.91 & Funnel shaped immature apex \\
\hline $37^{*}$ & 5.5 & 5.7 & 11.2 & 0.96 & Funnel shaped immature apex \\
\hline 36 & 12.9 & 6.6 & 19.5 & 1.81 & Mature tapering apex \\
\hline $35^{\star}$ & 5.9 & 6.2 & 12.1 & 0.95 & Mature apex with apical root blunting \\
\hline 34 & 10.2 & 6.2 & 16.4 & 1.64 & Mature tapering apex \\
\hline $33^{*}$ & 5.8 & 8.0 & 13.8 & 0.72 & Abrupt closure of apex with apical root blunting \\
\hline $32^{*}$ & 7.5 & 7.3 & 14.8 & 1.02 & Abrupt closure of apex with apical root blunting \\
\hline 31 & 9.1 & 7.1 & 16.2 & 1.28 & Mature blunt apex \\
\hline 41 & 9.2 & 7.1 & 16.3 & 1.29 & Mature blunt apex \\
\hline $42^{*}$ & 7.3 & 7.2 & 14.3 & 1.01 & Abrupt closure of apex with apical root blunting \\
\hline 43 & 13.8 & 8.0 & 21.8 & 1.7 & Mature tapering apex \\
\hline $44^{*}$ & 7.0 & 6.7 & 13.7 & 1.04 & Impacted tooth \\
\hline $45^{*}$ & 5.6 & 5.4 & 11.0 & 1.03 & Apical root blunting \\
\hline 46 & 12.1 & 6.1 & 18.2 & 1.98 & Mature tapering apex \\
\hline
\end{tabular}


neous pigmentation, scarring, and malformed nails, partial loss of vision along with dry mouth and multiple carious teeth in the present case were in consistence with the long term sequelae of SJS.

SRA and incomplete apical closure of multiple teeth was the interesting finding in the present case. In the SJS, the upper and lower epidermis is the most commonly affected. Necrosis of a few epidermal cells is seen in the mild lesion, whereas the severe lesion demonstrates the destruction of the whole epidermis. Similar histological features are seen in SJS lesions of the oral cavity, where the inner and outer enamel epithelia and root sheath of enamel follicle originate from the basal layer of the oral epithelia. The arrest of root development after SJS could be attributed to damage or destruction of keratinocytes of the Hertwig's epithelial root sheath or enamel follicle, which develops from oral epithelia. ${ }^{8,10,17,18}$ The developmental stage of the tooth at the time of the adverse event determines the effect on root growth. Teeth with complete or two-thirds root formation before this destruction are unlikely to demonstrate any effect except slight blunting of the root. Destruction after one-half of root formation can lead to cessation of further apical root elongation, and blunting of apex occurs due to continued deposition of secondary dentin by remaining odontoblasts. ${ }^{19,20}$ This is the reason for abrupt closure of apex in some of short rooted teeth. If this destruction happens before completion of one half of root, it inhibits the differentiation of odontoblasts from dental papilla cells resulting in the limited number of odontoblasts. It can result in malformation of the root dentin during root development. ${ }^{20}$ Similar findings were demonstrated in the CBCT scan of the patient. However, the full root formation in the canines and left lower premolar, in this case, was an exceptional observation. It can be hypothesized that since the tooth bud of these teeth is situated very deep, they escaped large epidermal cell necrosis. ${ }^{21}$

The CBCT radiological assessment indicated that the growth disturbance must have occurred around the age of 8-9 years, which coincides with the patient's history of severe illness and strengthens the association between SJS and SRA in the present case. Teeth with decreased root to crown $(\mathrm{R} / \mathrm{C})$ ratio measuring $<1.1$ are described as having SRA. ${ }^{12}$ The linear measurements on intraoral periapical radiograph, OPG, and CBCT scan have been used in literature to calculate the $\mathrm{R} / \mathrm{C}$ ratio. The $\mathrm{CBCT}$ is an advanced dental imaging technology that has the advantage of distortion-free image reconstruction and visualization in three planes as compared to conventional radiography and OPG. Also, localization of cementoenamel junction can be done more accurately on CBCT images, which is used as a reference point to obtain anatomical $\mathrm{R} / \mathrm{C}$ ratio. The method proposed by Choi et al. was used in the present case to measure $\mathrm{R} / \mathrm{C}$ ratio. ${ }^{11}$

SRA poses treatment challenge for the dentists. Teeth with SRA are more prone to root resorption due to the generation of greater mechanical stress during tooth movement. The presence of impacted teeth can also complicate and prolong the orthodontic treatment. The chances of immediate post-treatment relapse are more after orthodontic treatment in such teeth, and a permanent fixed splint is recommended. ${ }^{14}$ Compromised crown root ratio in SRA contraindicates the use of orthodontic extrusion or surgical crown lengthening procedures after the loss of coronal tooth structure; hence, the importance must be given to preventive and conservative methods of caries management. In this case, composite restorations were done as sufficient remaining dentin thickness was present. Apexification with mineral trioxide aggregate or bioceramic materials is essential for the endodontic treatment of non-vital teeth.

Appropriate management of patients with SRA requires accurate diagnosis that necessitates the collaboration of patient history, clinical, and radiographic examination. The routine radiographic methods have inherent limitations of $2 \mathrm{D}$ representation of the tooth and surrounding structures; the use of CBCT is necessary in such cases. CBCT allows for accurate assessment of the complex root canal morphology. The teeth can be simulated using the resin models, and a template can be prepared to minimize procedural errors during endodontic therapy.

\section{CONCLUSIONS}

The development of SJS at the age of tooth development can cause abnormal root formation. Multiple teeth were categorized as short root anomaly based on reduced root/ crown ratio measured on CBCT scan.

\section{REFERENCES}

1. Castana O, Rempelos G, Anagiotos G, et al. Stevens-Johnson syndrome: a case report. Ann Burns Fire Disasters 2009; 22:147-51.

2. Stevens AM, Johnson FC. A new eruptive fever associated with stomatitis and ophthalmia: report of two cases in children. Am J Dis Child 1922; 24:526-33.

3. Kim H-I, Kim S-W, Park G-Y, et al. Causes and treatment outcomes of Stevens-Johnson syndrome and toxic epidermal necrolysis in 82 adult patients. Korean J Intern Med 2012; 27:203-10.

4. Bastuji-Garin S, Rzany B, Stern R-S, et al. Clinical classification of cases of toxic epidermal necrolysis, Stevens-Johnson syndrome, and erythema multiforme. Arch Dermatol 1993; 129:92-6.

5. Harr T, French LE. Toxic epidermal necrolysis and Stevens-Johnson syndrome. Orphanet J Rare Dis 2010; 5:39.

6. Lee HY, Walsh SA, Creamer D. Long-term complications of StevensJohnson syndrome/toxic epidermal necrolysis (SJS/TEN): the spectrum of chronic problems in patients who survive an episode of SJS/ TEN necessitates multidisciplinary follow-up. Br J Dermatol 2017; 177:924-35.

7. Yang CW, Cho YT, Chen KL, et al. Long term sequelae of StevensJohnson syndrome/toxic epidermal necrolysis. Acta DermVenereol 2016; 96:525-9.

8. De Man K. Abnormal root development, probably due to erythema multiforme (Stevens-Johnson syndrome). Int J Oral Surg 1979; 
8:381-5.

9. Ranalli DN, Elliott MA, Whaley TM, et al. Stevens-Johnson syndrome: report of case with abnormal root development. ASDC J Dent Child 1984; 51:298-301.

10. Gaultier F, Rochefort J, Landru MM, et al. Severe and unrecognized dental abnormalities after drug induced epidermal necrolysis. Arch Dermatol 2009; 145:1332-3.

11. Choi S-H, Kim J-S, Kim C-S, et al. Cone-beam computed tomography for the assessment of root-crown ratios of the maxillary and mandibular incisors in a Korean population. Korean J Orthod 2017; 47:39-49.

12. Lind V. Short root anomaly. EurJ Oral Sci 1972; 80:85-93.

13. Apajalahti S, Hölttä P, Turtola L, et al. Prevalence of short-root anomaly in healthy young adults. Acta Odontol Scand 2002; 60:56-9.

14. Valladares Neto J, Rino Neto J, Paiva JB. Orthodontic movement of teeth with short root anomaly: Should it be avoided, faced or ignored? Dental Press J Orthod 2013; 18:72-85.
15. Apajalahti S, Arte S, Pirinen S. Short root anomaly in families and its association with other dental anomalies. Eur J Oral Sci 1999; 107: 97-101.

16. Fritsch PO, Sidoroff A. Drug-induced Stevens-Johnson syndrome/ toxic epidermal necrolysis. Am J Clin Dermatol 2000; 1:349-60.

17. Sangwan A, Saini HR, Sangwan P, et al. Stunted root development: A rare dental complication of Stevens-Johnson syndrome. J Clin Exp Dent 2016; 8:e462-4.

18. Bajaj N, Madan N, Rathnam A. Cessation in root development: ramifications of Stevens-Johnson syndrome. J Indian Soc Pedod Prev Dent 2012; 30:267-70.

19. Luder HU. Malformations of the tooth root in humans. Front Physiol 2015; 6:307.

20. Song Y, Lee N, Lee S, et al. Stevens-Johnson syndrome: a case report. J Korean Acad Pead Dent 2017; 44:455-60.

21. Moorrees CF, Fanning EA, Hunt EE. Age variation of formation stages for ten permanent teeth. J Dent Res 1963; 42:1490-502. 
Конусно-лучевая компьютерная томографическая характеристика аномалии короткого корня при индуцированном хлорохином синдроме СтивенсаДжонсона - клинический случай

\author{
Виджай Ядав, Сидхарта Шарма, Виджай Кумар, Амрита Чаула, Аджай Логани \\ Консервативная стоматология и эндодонтия, Учебный и научно-исследовательский центр дентальной медицины, Индийский институт \\ медищинских наук, Нью Дели, Индия
}

Адрес для корреспонденции: Виджай Ядав, Консервативная стоматология и эндодонтия, Учебный и научно-исследовательский центр дентальной медицины, Индийский институт медицинских наук, 110029 Нью Дели, Индия; E-mail: Id-dr.vjyadav@gmail.com

Дата получения: 31 августа 2020 Дата приемки: 11 марта 2021 Дата публикации: 28 февраля 2022

Образец цитирования: Yadav V, Sharma S, Kumar V, Chawla A, Logani A. Cone beam computed tomographic characterization of short root anomaly in chloroquine induced Stevens-Johnson Syndrome - a case report. Folia Med (Plovdiv) 2022;64(1):169-75. doi: 10.3897/folmed.64.e58178.

\begin{abstract}
Резюме
Синдром Стивенса-Джонсона (ССД) - это редкое заболевание с тяжёлой кожно-слизистой реакцией из-за инфекции или побочных реакций на лекарства. В данном случае показано влияние хлорохин-индуцированной ССД на развитие корня зуба. 20-летний мужчина индийского происхождения обратился в Клинику консервативной стоматологии и эндодонтии с серьёзной жалобой на застой пищи и чувствительность задних зубов верхней и нижней челюсти. В анамнезе у него была тяжёлая кожная реакция после приёма таблетки лариаго (хлорохин) для лечения малярии в возрасте восьми лет. Острый воспалительный иммунный ответ контролировали госпитализацией и введением стероидов и противовоспалительных препаратов. При клиническом осмотре выявлена сухость слизистых оболочек, кариозные зубы при адекватной гигиене полости рта. Панорамная рентгенография показала много зубов с короткими корнями. Детальная конусно-лучевая компьютерная томография (КЛКТ) показала здоровую трабекулярную структуру кости без периапикальной рентгенографии. У многих зубов наблюдаются короткие тупые корни с недоразвитыми верхушками. На основании измерения соотношения между корнем и коронкой сканера КЛКТ и соотнесения состояния развития зубов с анамнезом был поставлен диагноз аномалии короткого корня (АКК) после ССД, индуцированной хлорохином. Это первый отчёт, описывающий трёхмерные характеристики зубов с АКК у пациента с ССД. Акцент поставлен на диагностических, восстановительных и эндодонтических последствиях ССД.
\end{abstract}

\title{
Ключевые слова
}

ризомикрия, аномалия короткого корня, синдром Стивенса-Джонсона 